\title{
Alpha-2 Globulin Measurement
}

National Cancer Institute

\section{Source}

National Cancer Institute. Alpha-2 Globulin Measurement. NCI Thesaurus. Code C92254.

The determination of the amount of alpha- 2 globulin present in a sample. 